\title{
Statyba
}

\section{EXPERIMENTAL INVESTIGATIONS ON RC COLUMNS UNDER HORIZONTAL AND VERTICAL LOADING USING SHAKING TABLE}

\author{
R. Bairrão , R. Kačianauskas \& R. Kliukas
}

To cite this article: R. Bairrão , R. Kačianauskas \& R. Kliukas (1998) EXPERIMENTAL INVESTIGATIONS ON RC COLUMNS UNDER HORIZONTAL AND VERTICAL LOADING USING SHAKING TABLE, Statyba, 4:4, 244-251, DOI: 10.1080/13921525.1998.10531413

To link to this article: https://doi.org/10.1080/13921525.1998.10531413

Published online: 26 Jul 2012.

Submit your article to this journal $\llbracket$

Щ Article views: 57 


\title{
EXPERIMENTAL INVESTIGATIONS ON RC COLUMNS UNDER HORIZONTAL AND VERTICAL LOADING USING SHAKING TABLE
}

\author{
R. Bairrão, R. Kačianauskas, R. Kliukas
}

\section{Introduction}

The simulation of a structure behaviour and the study of its mechanical properties, close to real-life conditions, predict the quality of that designed structure. In spite of the existence of several numerical methods and design codes, an experimental testing remains the most powerful and reliable investigation tool. Advanced and innovative experimentation techniques, using computer controlled experimental measurements, provide a base for realistic simulation. Structural members submitted to combined longitudinal and transverse loading belong to the category of the most complicated experiments. Traditional experimentation techniques for testing bending elements under the action of longitudinal and transverse loading [12] are performed by using different testing machines while the tested elements are mainly two- or multi-span beams. In these cases, external loads are produced and controlled by testing machine devices.

There exists another type of structural members behaviour which may be described in a very simplified way by a cantilever beam model. Many columns, piers and towers belong to them. The above structural members have to be tested as vertical cantilever beams clamped (columns) at the bottom and loaded on the top by a vertical load $N$ and horizontal loads $H$ (Fig la). In many cases, vertical loads, which can be imposed by external pressure or prestressing remain constant. The most difficulties occur by producing the variable timedependent horizontal loads.

a b


c
Two main experimentation techniques are used, namely, reaction wall/floor systems and shaking tables. They exist in many laboratories of the European Union and are extensively used for testing concrete members, frames, walls, bridges and other structures. It should be underlined that computer controlled imposed displacements may be considered as a common feature of both techniques. In the first one, in spite of a complicated dynamic loading history, the external loading may be considered as quasi-static, since velocities are relatively small and mechanical properties remain insensible in respect of velocities.

Principal test-up of a reaction wall/floor technique is illustrated in Fig 1b. Here, servo-hydraulic actuators are used to apply time $t$ dependent horizontal displacement $u(t)$ and so to produce horizontal force $H(t)$. One of the new large-scale reaction wall/floor system described in [3] is located in Northern Italy at Ispra. It basically consists of a $21 \mathrm{~m}$ wide wall having height $L=16 \mathrm{~m}$ and thickness $t=4$ $\mathrm{m}$. The wall was designed to resist forces typically of several thousands $\mathrm{kN}$.

Shaking table testing started its development in the early fifties. It typically consists of a large, rectangular platform (or table) that is driven in up to six degrees of freedom by servo-hydraulic actuators. Test specimens are fixed to the platform and shaken. In a single-dimensional case (Fig 1c), horizontal displacement $u(t)$ is imposed by actuators while horizontal force $H(t)$ is mainly inertia force which occurs due to excitation of an external mass $m$.

Fig 1. Schematic illustration of loading for vertical members:

a) column beam with loading, b) reaction wall/floor system, c) shaking table 
Shaking tables are essential tools in earthquake engineering research since they allow to study the effects of true inertia forces on the specimens. Normally, the specimens are constructed at model scale, and this can limit the scope of the tests in some cases. In contrast, reaction wall test rigs allow full scale specimens to be tested but not with true inertia forces.

Several shaking tables throughout Europe are being used to research the dynamic effects on structures. Nowadays, the shaking table activity in Europe is coordinated by "European Consortium of Shaking Tables (ECOEST)", the main activities and technical data of which are presented in [4]. A new type of 3D shaking table was built in the National Laboratory of Civil Engineering (LNEC) in Lisbon [4-7].

The present paper is mainly focussed on the description of shaking table technique used to test concrete members. The specimens are R.C. columns working as plane cantilever beams under the action of horizontal and vertical concentrated loads. Two tests, up to failure on, two high-strength reinforced concrete specimens with annular cross-section were carried out at the LNEC [8]. Detailed descriptions of shaking table testing capability, construction of the specimens, the set-up, the testing procedure and the acquisition of data are given in the text. Finally, selected histories of registered displacements and horizontal load, as well as computed load-displacement diagrams, are presented in order to illustrate the experimental methodology as well as the behaviour of the specimens in the cracking phase.

\section{Shaking table testing capability}

Shaking table testing plays a very prominent role in the validation of design procedures because it is the only possibility to directly generate earthquake and other dynamic effects under conditions allowing their systematic and scientific observation. In order to advance its experimental activity in engineering, which started in the late fifties, LNEC studied and built a new type of shaking table that was conceived for the testing of civil engineering structures such as buildings and bridges, being, however, also used for the validation of mechanical and electrical equipment.

The new simulator has three independent translational degrees of freedom which are driven by hydraulic actuators, whereas its rotational degrees of freedom are eliminated by torque tube systems, one for each axis (roll, pitch and yaw). Under the horizontal cranks, it can be inserted either passive gas actuators, to cope with the dead weights of the shaking table and of the testing specimen, or rigid blocks eliminating the vertical motion of the table. The platform was designed to work in a frequency range from zero up to about $15 \mathrm{~Hz}$.

In order to have a shaking table simulating only the horizontal and vertical motions, the platform rotational degrees of freedom are eliminated by torque tube systems, one for each axis. Each system is composed of a torsionally very stiff torque tube which can rotate around its longitudinal axis and is supported at both ends by bearings. A general perspective of the 3D LNEC earthquake simulator is shown in Fig 2.

At each end the torque tube is linked, by way of a crank, with a stiff connecting rod. This, in turn, is connected to the platform. The vertical connecting rods are pinned at both ends, and horizontal motion of the platform is allowed. When the platform moves vertically, it either pulls or pushes the connecting rods, rotating both cranks by the same angular amount and torque tube likewise; thus, no forces whatsoever arise. In fact, if there is an overturning moment inducing a rotation of the platform, then vertical movement in opposed directions appears at the upper end of the connecting rods, which in turn causes small opposite rotating forces in the cranks. This is resisted by a large reaction force generated through torsional deformation of the very stiff torque tubes, resulting in an insignificant platform rotation. Main characteristic of the 3D LNEC shaking table may be found in [7].

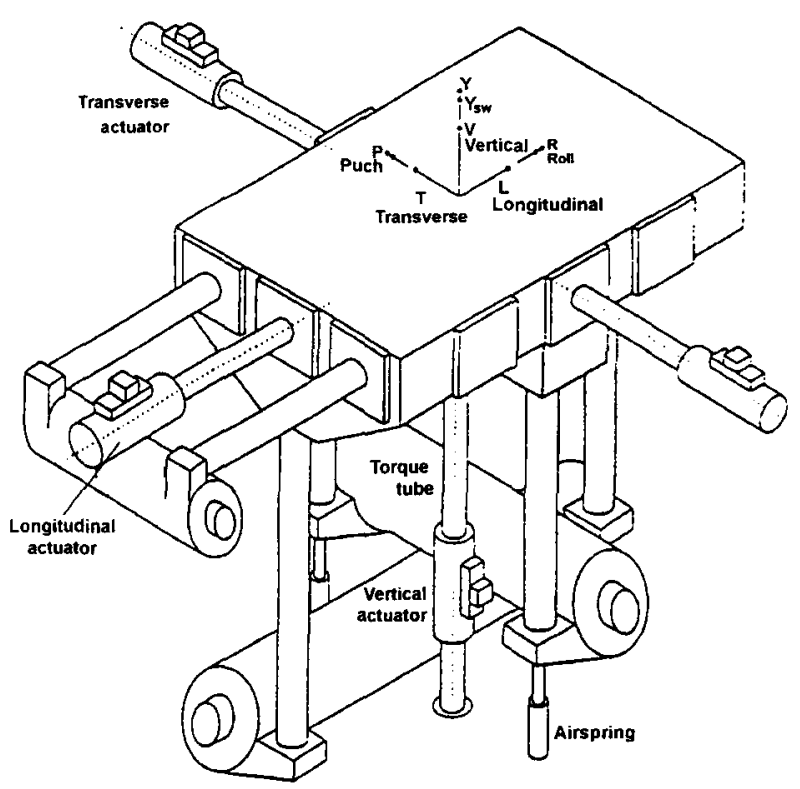

Fig 2. General perspective of the 3D LNEC simulator 


\section{Construction of the specimens}

The specimen being tested presents high-strength concrete $f_{c}=80 \mathrm{MPa}$ column of annular cross-section reinforced with longitudinal bars and spiral wire. The $8 \emptyset 10 \mathrm{~mm}$ A500 steel bars are used for longitudinal reinforcement while $\varnothing 6 \mathrm{~mm}$ A500 steel wire was used for spiral reinforcement. The entire specimen was produced as a monolithic unit consisting of a massive base and a tested column. The specimen contains special holes, voids and stiffening details necessary for application of external loads and guaranty of testing conditions. Geometry of the entire specimen is presented in Fig 3, while characteristic dimensions are presented in Table 1.

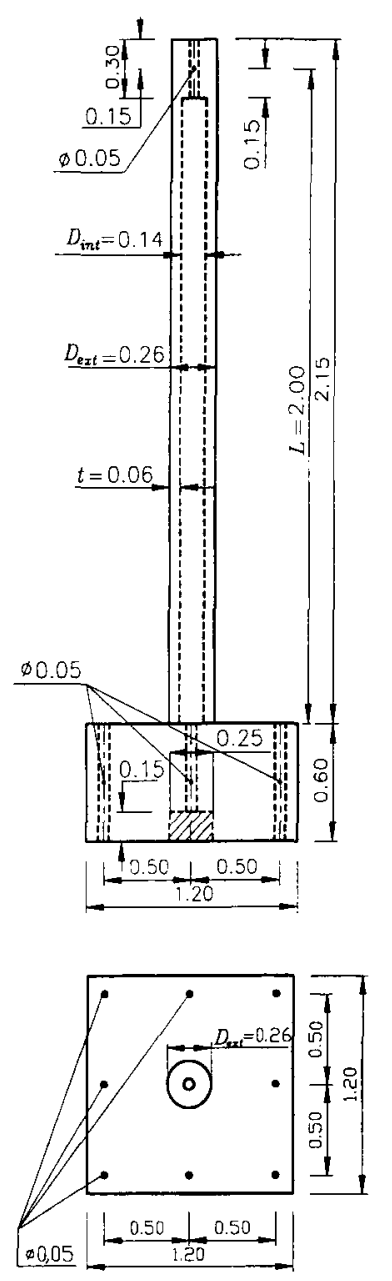

Fig 3. Geometry of the specimen

Table 1. Values of characteristic dimensions of the specimen

\begin{tabular}{|c|c|c|c|c|c|c|}
\hline $\begin{array}{l}\text { Para- } \\
\text { meter }\end{array}$ & $\begin{array}{c}\text { Height } \\
L\end{array}$ & $\begin{array}{c}\begin{array}{c}\text { External } \\
\text { diameter }\end{array} \\
D_{\text {ext }}\end{array}$ & $\begin{array}{c}\begin{array}{c}\text { Internal } \\
\text { diameter }\end{array} \\
D_{i n t}\end{array}$ & $\begin{array}{c}\text { Wall } \\
\text { thick- } \\
\text { ness } \\
t\end{array}$ & $\begin{array}{c}\text { Rein- } \\
\text { forcement } \\
\text { radius } \\
r_{s}\end{array}$ & $\begin{array}{c}\text { Rein- } \\
\text { forcement } \\
\text { step } \\
s\end{array}$ \\
\hline Unit & $\mathrm{mm}$ & $\mathrm{mm}$ & $\mathrm{mm}$ & $\mathrm{mm}$ & $\mathrm{mm}$ & $\mathrm{mm}$ \\
\hline Value & 215 & 0 & U & 60 & 105 & $\begin{array}{c}50 \text { and } \\
100\end{array}$ \\
\hline
\end{tabular}

\section{Testing technique, instrumentation and data acqui-} sition

As said previously, the tested column was considered as a vertical cantilever beam loaded by combined vertical and horizontal actions. Principal loading scheme is presented in Fig 1c.

The vertical load $N=187.5 \mathrm{kN}$, producing axial force, was applied before the test and remained constant during the entire testing period. It was implemented by prestressing as cable placed inside (at the central line) of the column and connected to the top and bottom.

Horizontal time-dependent load $H(t)$ was produced by the motion of the shaking table and inertia mass. External mass involves additional mass and the connecting rod. The total value of external mass was $m=12 \mathrm{t}$. Motion of shaking table was described as a function of transverse horizontal time-dependent displacement $u(t)$. In the present experiments, sine-type signal controlled by amplitude $u$ and frequency $\theta$ was used. Loading history was divided into five stages. Each stage is characterised by different amplitude, frequency, duration and character of the motion. Two equivalent speciments, V1 and V2, were tested in the framework of the current investigation. All loading stages were denoted by notations $\mathrm{S} 1, \mathrm{~S} 2$, etc.

21 channels were acquired for recording several parameters during the experiments. The list of channels is presented in Table 2. The table contains consecutive numbers and identifications of channels, description of the acquired parameters and instrumentation used to measure the signals.

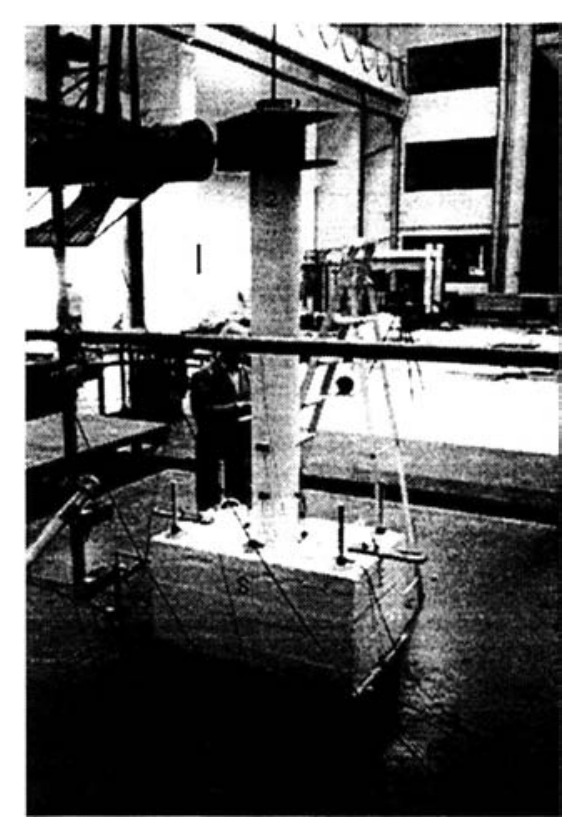

Fig 4. Location of instrumentation on the specimen 
13 channels (numbers from 1 to 13 ) were used to measure the displacements of prescribed points of the specimen during the loading history. Optical and inductive transducers were applied to measure different displacements. Location of all displacement transducers is shown in Fig 5. For identification of orientation of the specimen, all sides of them are posted by capital letters $W$ (West), $S$ (South), $E$ (East) and $N$ (North). Transverse (in plane) direction in respect of the movement of shaking table (loading of the specimen) is oriented along axis $W$ $E$, while out of plane direction is oriented along axis $S-N$. External (inertia) mass is added from the side $W$. Orientation of the specimen is shown in Fig $5 \mathrm{~d}$.

Horizontal displacements. Location of transducers on the sides $W, S$ and $E$ is shown in Figs 5a-c, respec- tively. Horizontal movements are controlled using optical transducers mainly fixed on the side $S$. Transducers d8d11 (Fig 5b) control transverse (in plane) displacements of prescribed points of the column while transducer $\mathrm{d} 12$ (Fig 5c) controls out of plane displacement. The transducer $\mathrm{d} 13$ controls transverse displacement of shaking table (Fig 5b). Local displacements of the specimen in respect of shaking table are controlled by inductive transducer d 1 (Fig 5a).

Vertical displacements. Measurements of vertical (longitudinal) displacements of the prescribed points of the column are mainly devoted to the investigation of longitudinal deformations. Such displacements are measured by inductive transducers $\mathrm{d} 2-\mathrm{d} 7$ located on the sides $W$ and $E$ (Fig 5a-c).

Table 2. Information on measurements of signals

\begin{tabular}{|c|c|c|c|}
\hline Channel & Identificator & Description & Transducer \\
\hline 1 & $\mathrm{~d} 1$ & Horizontal in plane displacement of the base in respect of shaking table & Inductive (W100) \\
\hline 2 & $\mathrm{~d} 2$ & $\begin{array}{l}\text { Vertical displacement of the outside point of column (side } W \text {, distance from the } \\
\text { base } l_{1}=130 \mathrm{~mm} \text { ) }\end{array}$ & Inductive (W20) \\
\hline 3 & d3 & $\begin{array}{l}\text { Vertical displacement of the outside point of column (side } W \text {, distance from the } \\
\text { base } l_{2}=520 \mathrm{~mm} \text { ) }\end{array}$ & Inductive (W50) \\
\hline 4 & $\mathrm{~d} 4$ & $\begin{array}{l}\text { Vertical displacement of the outside point of column (side } W \text {, distance from the } \\
\text { base } l_{3}=260 \mathrm{~mm} \text { ) }\end{array}$ & Inductive (W50) \\
\hline 5 & d5 & $\begin{array}{l}\text { Vertical displacement of the outside point of column (side } E \text {, distance from the } \\
\text { base } l_{1}=130 \mathrm{~mm} \text { ) }\end{array}$ & Inductive (W20) \\
\hline 6 & d6 & $\begin{array}{l}\text { Vertical displacement of the outside point of column (side } E \text {, distance from the } \\
\text { base } l_{2}=520 \mathrm{~mm} \text { ) }\end{array}$ & Inductive (W50) \\
\hline 7 & d7 & $\begin{array}{l}\text { Vertical displacement of the outside point of column (side } E \text {, distance from the } \\
\text { base } l_{3}=260 \mathrm{~mm} \text { ) }\end{array}$ & Inductive (W50) \\
\hline 8 & $\mathrm{~d} 8$ & $\begin{array}{l}\text { Horizontal in plane displacement of the outside point of column (side } S \text {, distance } \\
\text { from the base } l_{4}=260 \mathrm{~mm} \text { ) }\end{array}$ & Optical \\
\hline 9 & d9 & $\begin{array}{l}\text { Horizontal in plane displacement of the outside point of column (side } S \text {, distance } \\
\text { from the base } l_{5}=520 \mathrm{~mm} \text { ) }\end{array}$ & Optical \\
\hline 10 & $\mathrm{~d} 10$ & $\begin{array}{l}\text { Horizontal in plane displacement of the outside point of column (side } S \text {, distance } \\
\text { from the base } l_{6}=1040 \mathrm{~mm} \text { ) }\end{array}$ & Optical \\
\hline 11 & d11 & $\begin{array}{l}\text { Horizontal in plane displacement of the top point of column (side } S \text {, distance from } \\
\text { the base } l_{7}=2150 \mathrm{~mm} \text { ) }\end{array}$ & Optical \\
\hline 12 & $\mathrm{~d} 12$ & $\begin{array}{l}\text { Horizontal out of plane displacement of the outside point of column (side } E \text {, dis- } \\
\text { tance from the base } l_{6}=1040 \mathrm{~mm} \text { ) }\end{array}$ & Optical \\
\hline 13 & $\mathrm{~d} 13$ & Horizontal in plane displacement of the shaking table (side $S$ ) & Optical \\
\hline 14 & alt & Horizontal in plane acceleration of the shaking table & Acceleromet. \\
\hline 15 & $\mathrm{a} 2 \mathrm{t}$ & Horizontal in plane acceleration of the shaking table & Acceleromet. \\
\hline 16 & a21 & Horizontal out of plane acceleration of the shaking table & Acceleromet. \\
\hline 17 & a31 & Horizontal out of plane acceleration of the shaking table & Acceleromet. \\
\hline 18 & $\mathrm{aml}-\mathrm{L}$ & Horizontal out of plane acceleration of the top point of column & Acceleromet. \\
\hline 19 & aml-T & Horizontal in plane acceleration of the top point of column & Acceleromet. \\
\hline 20 & At-M & Horizontal in plane acceleration of external mass & Acceleromet. \\
\hline 21 & $\mathrm{HL}$ & Horizontal inertia force & Force cell \\
\hline
\end{tabular}




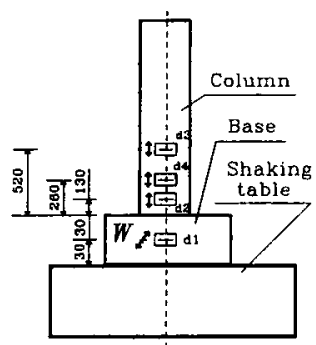

c

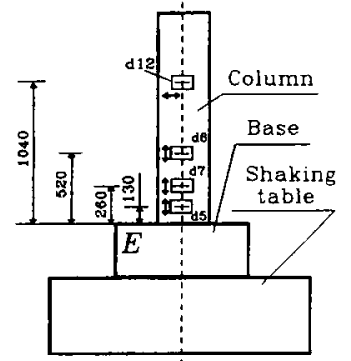

b

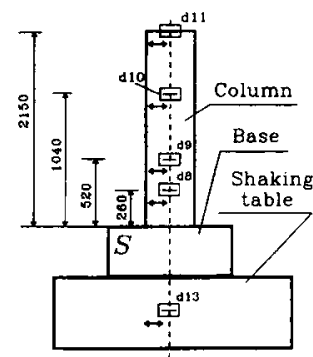

d

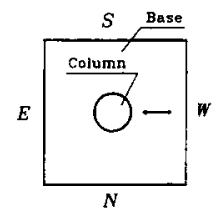

Fig 5. Location of displacement gauges: a) side $E$, b) side $S$, c) side $E$, d) orientation of sides of the specimen

7 cannels were to acquire the accelerations, using accelerometers. Two devices a1t and a2t measured horizontal transverse (in plane) accelerations while another two longitudinal accelerations of the shaking table. Devices am1-L and am1-T control acceleration of the top point of the column in plane and out of plane directions. Device At-M measured the external inertia mass acceleration.

The horizontal force was measured by a loading cell HL equipped as part of the connection $20 \mathrm{~d}$.

Optical displacement transducers HAMAMATSU $^{\circledR}$ (comprising lens, sensor head and led target) and HAMAMATSU ${ }^{\circledR}$ conditioning device PSH Contoller C2399 were used for measuring the horizontal displacements.

Hottinger Baldvin Messtechnik w100, w50 and w20 inductive displacement transducers having working stroke at $200 \mathrm{~mm}, 100 \mathrm{~mm}$ and $40 \mathrm{~mm}$ respectively were mainly used to measure vertical displacements. The transducers were connected to a set of whetstone bridge amplifiers. High frequency ENDEVCO ${ }^{\text {(3) }}$ model $7290 \mathrm{~A}(0-600 \mathrm{~Hz})$ variable capacitance accelerometers and ENDEVCO $^{\circledR}$ model 106 piezoresistive bridge sig nal conditioners with pre-set $100 \mathrm{~Hz}$ anti-aliasing 8 pole "Butterworth" filters were used for measuring accelerations. The 2518-121 Series of Instron Loading Cell having a dynamic capacity of $500 \mathrm{kN}$ was used for measuring the horizontal inertia force.

\section{Illustration of the experimental results}

Two concrete specimens identified as V1 and V2 were produced and tested in LNEC. Establishment of mechanical characteristics and investigation of evolution of damage was the main goal of the experimental research. For these purposes evolution of damage was observed in consecutive stages with different loading histories (different amplitudes and frequencies). As an example, the results obtained with specimen V2 after stage $\mathrm{S} 4$ are presented below. This stage may be characterised as the one where progressive development of cracking in concrete was observed.

Evolution of the specimen damage during the cyclic loading may be described by a force-displacement diagram $H \cdot u$. The time-dependent horizontal force $H(t)$ was measured directly while the horizontal displacement $u(t)$ of the specimen was obtained indirectly through different measured values. Characteristic displacements used for the above purpose are illustrated in Fig 6.

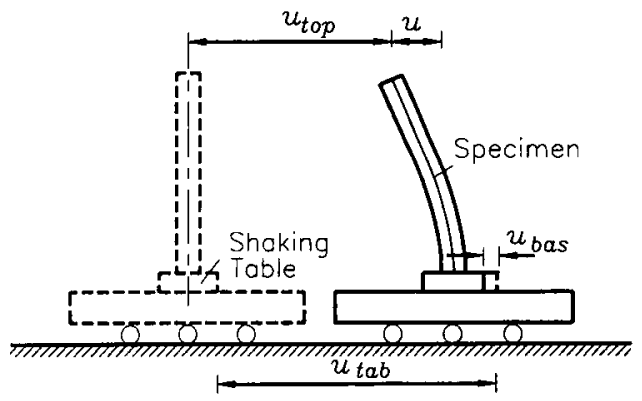

Fig 6. Illustration of measured characteristic displacements

Transverse displacement of the specimen $u(t)$ may be expressed as the difference between the displacements at the top and the bottom. The top displacement $u_{t o p}$ is recorded directly. The bottom displacement is the controlled displacement of the shaking table $u_{t a b}$ corrected by the relative displacement of the specimen base in respect of shaking table $u_{b a s}$. Finally, the transverse displacement of the specimen may be expressed as

$$
u=u_{t a b}-u_{b a s}-u_{t o p}
$$

The acquired displacements $u_{t a b}(t), u_{b a s}(t), u_{t o p}(t)$ as well as horizontal force $H(t)$ are presented in Fig 7 , while the transverse displacement $u(t)$ and force-displacement diagram $H-u$ are presented in Fig 8. The controlled displacement of the shaking table $u_{t a b}(t)$ identified by $\mathrm{d} 13$ (Fig 7a) is designed as having a progressively increasing amplitude during the first phase (interval between 2.5 and $12.5 \mathrm{sec}$ ) and a constant amplitude during the second phase (interval between 12.5 and $22.5 \mathrm{sec}$ ). However, this signal 
does not produce adequate transverse displacements and forces. During the first 9 seconds the external mass acts actually as a dead mass, in fact transverse displacement $u_{t o p}(t)$ identified by $\mathrm{d} 11$ (Fig $7 \mathrm{c}$ ) remains almost zero while in the next phase motion it produces increasing amplitudes. It should be noted that relative displacement of the base $u_{\text {bas }}(t)$ identified by $\mathrm{d} 1$ (Fig 7b) is negligibly small. As a result of the excitation an increase of the horizontal force $H(t)$ identified by HL
(Fig 7d) is observed. Similar displacements $u(t)$ (Fig 8a) were found by calculations according to (1). The first phase produces a smaller loop on the force-displacement diagram (Fig 8b) with an average stiffness $k_{1}$ while higher load leads to new cracks and change of stiffness. The second phase may be characterised by lower stiffness $k_{2}$ and another loop. The observed cracks and damage after stage 5 are illustrated in Fig 9. a)

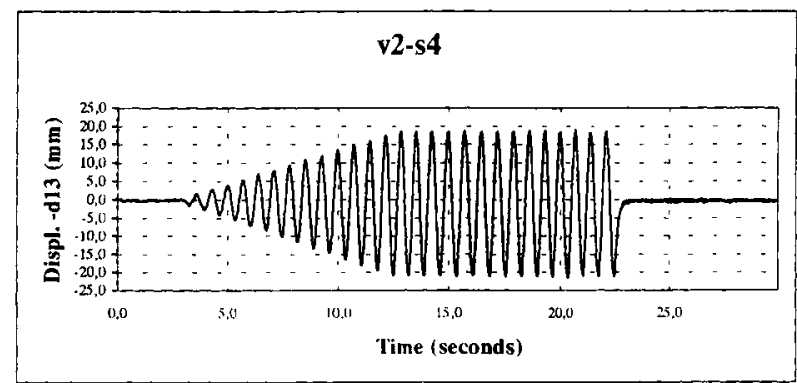

c)

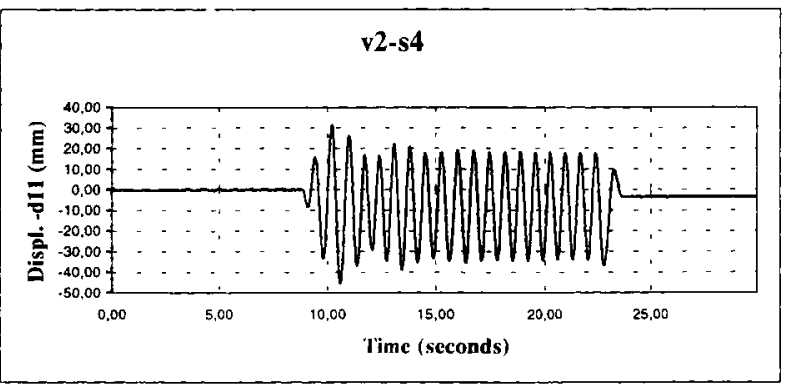

b)

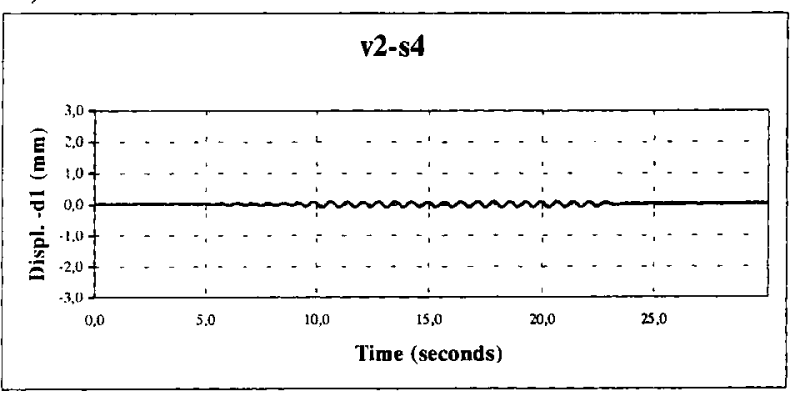

d)



Fig 7. Selected characteristics of the specimen $V_{2}$ measured during the forth stage $S 4$ of the experiment: a-c) displacements; d) horizontal load

b)

a)

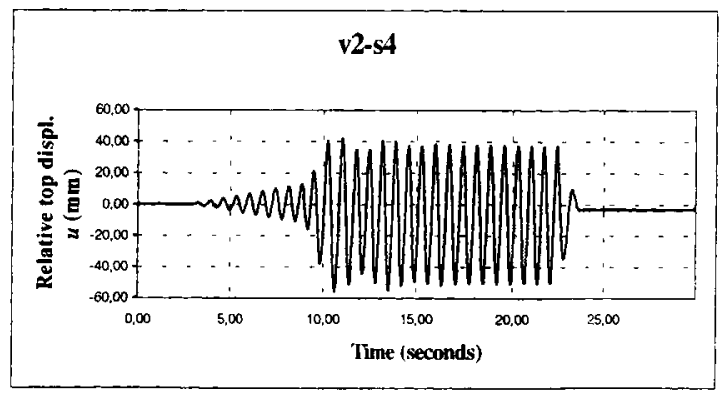

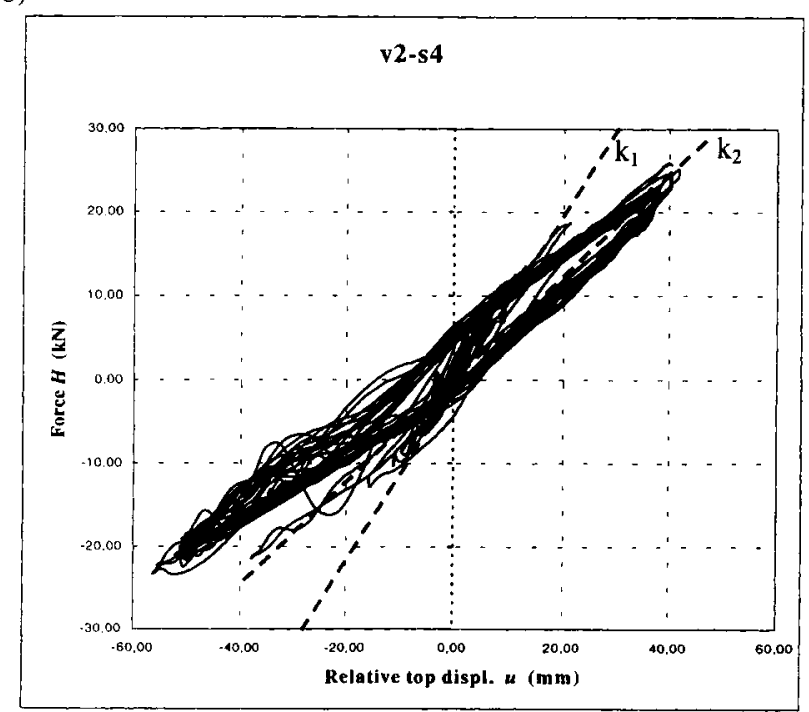

Fig 8. Calculated characteristics of the specimen $V_{2}$ during the forth stage $\$ 4$ : a) relative transverse displacement of the top of specimen; b) force-displacement diagram 


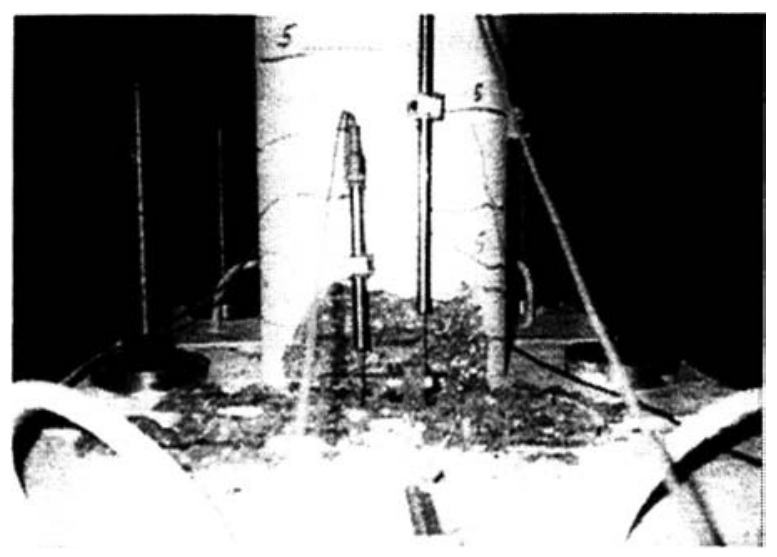

Fig 9. V2 specimen after stage S5

\section{Conclusion}

LNEC shaking table capability to produce a wide range of complicated time-dependent loading is demonstrated. New computer controlled equipment allows the simulation of seismic loading as well as different types of simpler variable loading with controlled frequencies, amplitudes, etc. The shaking table testing capabilities and technical details for testing reinforced high-strength concrete specimens under the action of combined constant longitudinal and variable transverse loading are presented. Testing methodology, equipment and instrumentation enable to observe the behaviour of the specimen and evolution of cracking and damage starting at the elastic range up to failure.

Experimental investigation of this type of variable loads have major importance for the structures in Lithuania. The experimental results obtained will be used for modelling reinforced high-strength concrete columns as well as to understand better the properties of high-strength concrete.

\section{Acknowledgements}

The studies described in this report were partially funded by the European Community Programme "Access to Large Scale Facilities - The Large Installations Plan" in the framework of the "European Consortium of Earthquake Shaking Tables", ECOEST, contract ERBCHGEST 920010, supplementary agreement ERBCIPDCT 940089, PECO, for the support to scientists from Central and Eastern European Countries. This funding is gratefully acknowledged.

\section{References}

1. А.Н. Тетиор, В.Н. Померанец. Обследование и испытание сооружений. Киев: Выща школа, 1998. 209 с.

2. О.В. Лужин, А.Б. Злочевский, А.И. Горбунов, В. А. Волохов. Обследование и испытание сооружений. М.: Стройиздат, 1987. $263 \mathrm{c}$.

3. Pseudodynamic and shaking table tests on R.C. bridges (Ed. A.V.Pinto). ECOEST/PREC8 Report, No 5, November 96. Lisboa, LNEC, 1996. 140 p.
4. Standartisation of shaking tables (Ed. A.Crewe). ECOEST/ PREC8 Report, No 1, July 97. Lisboa, LNEC, 1997. 196 p.

5. C. Oliveira-Costa, F. J. Carvalhal and R. T. Duarte. The performance of an adaptive control system on shaking table testing of structure elements // Proc. of 10th European Conf. on Earthquake Engineering, Vienna, Austria, 1994, p. 120-126.

6. F. Pires, R. Bairrão, S. R. Costa e Silva. Earthquake Behaviour of Masonry Infilled Reinforced Concrete Frames. Test of Models MD3, MD4, MD5 and MD6. Reports 48/95, 70/95, 126/95 and 137/95 - C3ES. Lisbon, National Laboratory for Civil Engineering, 1995. 127 p., 155 p., 162 p., 170 p.

7. R. Bairrão. Reinforced concrete structures - non-linear analysis and earthquake failure // Summer school on failure in structures under TEMPUS JEP 8098. Kielce-Ameliovka, June 2-6, 1997, p. 263-288.

8. R. Bairrão, C. Vaz, J. Duque. Dynamic tests on high-strength R.C. columns under combined vertical and horizontal loading. LNEC/C3 ES IESES-236/98 181 p.

Iteikta 19980702

\section{EKSPERIMENTINIS DIDELIO STIPRUMO GELŽBETO- NINIU ELEMENTU TYRIMAS VIBRACINIU STALU, VEIKIANT HORIZONTALIOSIOMS IR VERTIKALIO- SIOMS APKROVOMS}

\section{R. Bairrão, R. Kačianauskas, R. Kliukas}

\section{S a n tra u a}

Naujo tipo konstrukciju kūrimas ir idiegimas imanomas tik visapusiškai ištyrus jų darbą ir mechanines savybes, veikiant apkrovoms, artimoms eksploatacinèms. Šalia teorinès analizès ir skaitinių eksperimentų labai svarbūs yra fizikiniai eksperimentai. Tobulèjant eksperimentinei ìrangai ir matavimo aparatūrai galima atlikti vis sudètingesnius eksperimentus (ir gauti labai tikslius rezultatus), atitinkančius imituojamą konstrukciju darbą realiomis salygomis.

Šiuo metu bandant statybines konstrukcijas, Europoje dominuoja du horizontaliosios (skersinès) apkrovos perdavimo būdai, leidžiantys gauti sudètingas, cikliškai kintancias apkrovas: a) naudojant jegos grindis ar siena; b) naudojant vibracinius stalus.

Būdingas abieju metodų bruožas, kad bandymų metu vykstantys procesai yra sąlygiškai greiti dinaminiai ar pseudodinaminiai kompiuteriais valdomi procesai. Vertikaliosios apkrovos dažniausiai būna pastovios. Jos sukeliamos pridedant išorinius krūvius ar iš anksto ịtempiant bandomus elementus. Nepaisant sudètingu jègu kitimo laiko atžvilgiu dẻsningumų, išorinès jègos yra laikomos kvazistatinèmis, nes judèjimo greičiai yra palyginti maži ir neturi praktinès itakos bandinių mechaninèms savybèms. Atliekant bandymus, naudojant jègos sienas ir grindis, eksperimento metu kompiuteriu valdomi horizontalieji poslinkiai $u(t)$.

Atliekant bandymus ant vibracinio stalo (1b pav.) vibracinio stalo poslinkiai $u(t)$ yra valdomi kompiuteriu. Šie poslinkiai ir išorinè masè $m$ sukelia horizontaliassias inercijos jègas $u(t)$ (1c pav.).

Vienas iš keturių pagal savo techninius parametrus ir konstrukciją moderniausių Europoje statybinių konstrukcijų bandymo stalu irengtas Portugalijos Nacionalineje statybos laboratorijoje. Šioje laboratorijoje straipsnio autoriai eksperimentiškai tyre gelžbetoninių žiedinio skerspjūvio elementu darbą veikiant išilginei pastovaus dydžio gniuždymo jẻgai ir kintamojo ženklo horizontaliajai (skersinei) jègai. Horizontaliają jègą sudarè inercinè išorinès masès $m$ jèga, kurią sukèlè vibracinių stalu virpinamo tiriamo elemento judejimas. Masè $m$ su bandomu elementu buvo sujungta šarnyriškai. 
Kompiuterizuota eksperimentinè iranga leido sudaryti sudètingą gelžbetoninių žiedinio skerspjüvio kolony bandymo programa. Gelžbetonines kolonos buvo pagamintos is didelio stiprumo vibruotinio betono $\left(f_{c} \approx 80 \mathrm{MPa}\right)$ ir armuotos A500 plieno išilgine ir skersine-spiraline armatūra.

Straipsnyje taip pat supažindinama su bandinio konstrukcija, matavimo laboratorine iranga, jos išdèstymu ir eksperimento metu matuojamais dydžiais: tam tikrų taškų poslinkiais, pagreičiais ir horizontaliaja jèga.

Bandymu rezultatai iliustruojami būdingų matuojamų dydžiu kitimo laikui bėgant grafikais, kurie parodo bandinio darbą pleišejimo stadijoje ( 7 ir 8 pav.).

ROGÉRIO BAIRRÃO. Doctor, Senior Researcher. Earthquake Testing Division, Centre for Studies and Equipment in Earthquake Engineering, National Laboratory for Civil Engineering, Av. Brasil 101, 1799 Lisboa Codex, Portugal.

Mechanical engineer (Lisbon Technical University, 1977). MSc (applied Mechanics, Paris VI University, 1983). $\mathrm{PhD}$, (energy mechanics, Paris VI University, 1986). PhD, (mechanical Engineering, Lisbon Technical University, 1987). Lecturer of applied mechanics, 1977/82, Lisbon Technical University. Research Engineer, 1982/86, French Atomic Authority. Researcher, 1986/93, Portuguese National Laboratory for Civil Engineering (presently Head of Earthquake Testing Division). Author of over 100 scientific reports and communications to scientific meetings. Research interests: non-linear behaviour of reinforced concrete structures, applied mechanics, earthquake testing of structures.

Rimantas KaČIANAUSKAS. Doctor Habil, Professor. Dept of Strength of Materials. Vilnius Gediminas Techical University Saulètekio al. 11, LT-2040 Vilnius, Lithuania.

PhD (structural mechanics, 1982). Dr Habil, (1996). Professor (1997). Scientific visits: University of Stuttgart and Swiss Federal Institute of Technology, Zurich. Author of 1 monograph and over 80 papers. Research interests: computational mechanics, finite element method, computer modelling of structures.

Romualdas KLIUKAS. Doctor, Associate Professor. Dept of Strength of Materials. Vilnius Gediminas Technical University, Saulètekio al. 11, 2040 Vilnius.

PhD (building structures, 1989). Researcher at the Dept of Reinforced Concrete Structures. Since 1989 senior assistant at the Dept of Strength of Materials. Research visit to Buildings Scientific-Technical Research Centre (France, 1990-91). Author of over 40 consultancy works (assessment of serviceability of various structures, renovation projects of buildings). Research interests: structures in civil engineering, renovation of buildings, reinforced concrete theory, research and design of reinforced concrete structures applying high-strength concrete and high-yield reinforcement. 